NBER WORKING PAPER SERIES

\title{
INTENSIFIED REGULATORY SCRUTINY AND BANK DISTRESS IN NEW YORK CITY DURING THE GREAT DEPRESSION
}

\author{
Gary Richardson \\ Patrick Van Horn \\ Working Paper 14120 \\ http://www.nber.org/papers/w14120
NATIONAL BUREAU OF ECONOMIC RESEARCH
1050 Massachusetts Avenue
Cambridge, MA 02138 \\ June 2008
}

Comments from Naomi Lamoreaux inspired us to investigate this topic. We thank Jeremy Atack, an anonymous referee, and other colleagues and friends for comments that improved this essay. NSF Grant D/SES-0551232 funded portions of this research. The views expressed herein are those of the author(s) and do not necessarily reflect the views of the National Bureau of Economic Research.

NBER working papers are circulated for discussion and comment purposes. They have not been peerreviewed or been subject to the review by the NBER Board of Directors that accompanies official NBER publications.

(C) 2008 by Gary Richardson and Patrick Van Horn. All rights reserved. Short sections of text, not to exceed two paragraphs, may be quoted without explicit permission provided that full credit, including (C) notice, is given to the source. 
Intensified Regulatory Scrutiny and Bank Distress in New York City During the Great Depression Gary Richardson and Patrick Van Horn

NBER Working Paper No. 14120

June 2008

JEL No. E42,G21,N1,N12

\title{
ABSTRACT
}

New data reveals that bank distress peaked in New York City, at the center of the United States money market, in July and August 1931, when the banking crisis peaked in Germany and before Britain abandoned the gold standard. This paper tests competing theories about the causes of New York's banking crisis. The cause appears to have been intensified regulatory scrutiny, which was a delayed reaction to the failure of the Bank of United States, rather than the exposure of money-center banks to events overseas.

\author{
Gary Richardson \\ Department of Economics \\ University of California, Irvine \\ Irvine, CA 92697-5100 \\ and NBER \\ garyr@uci.edu \\ Patrick Van Horn \\ Department of Economics \\ 4901 Evergreen Road \\ Dearborn, Michigan 48128 \\ patrickv@umd.umich.edu
}




\section{Introduction}

Information recently discovered in the National Archives reveals the date of distress (i.e. terminal suspension, temporary suspension, voluntary liquidation, or merger forced by financial difficulties) for all banks operating in the United States. This detailed data demonstrates that bank failure rates peaked in New York City, at the center of the United States money market, in July and August 1931. During those months, the banking crisis peaked in Germany. One month later, Britain abandoned the gold standard. ${ }^{1}$

According to the conventional academic wisdom, Britain's departure from gold transmitted a financial crisis in Europe to the United States. ${ }^{2}$ Anticipating a similar action on the part of American monetary authorities, central banks and private holders in Europe converted dollar assets in the New York money market into gold. The unloading of bills swiftly assumed panic proportions. Gold outflows rose rapidly, draining funds from the United States and threatening the solvency of financial institutions in the central money market. To stop the international drain, the Federal Reserve System raised the discount rate from $1 \frac{1}{2}$ to $3 \frac{1}{2}$ percent between October 9 and October 16. This was the

sharpest rise within so brief a period in the whole history of the system, before or since ... the move intensified internal financial difficulties and was accompanied by a spectacular increase in bank failures and runs on banks. ${ }^{3}$

Economists refer to this reaction as golden fetters. ${ }^{4}$

\footnotetext{
1 The forms may be found in the National Archives and Record Administration [hereafter NARA], Record Group 82, Federal Reserve Central Subject File, file number 434.-1, "Bank Changes 1921-1954 Districts 1929-1954 Consolidations, Suspensions and Organizations-St. 6386 a,b,c, (By States) 1930-1933” [hereafter Bank Changes]. The forms are filed alphabetically by state, name of town or city, and name of bank. Multiple entries for individual banks appear in chronological order. For additional information about this source, see Gary Richardson, "Records;" Richardson, "Bank Distress ... New Evidence;” Richardson, "Bank Distress ... Illiquidity-Insolvency Debate," and Richardson; "Quarterly Data."

2 Milton Friedman and Anna Schwartz, Monetary History; Barry Eichengreen, Golden Fetters; Peter Temin, Lessons.

3 Friedman and Schwartz, Monetary History, p. 317

4 Eichengreen, Golden Fetters
} 
Combining the new data and the conventional wisdom creates a paradox of timing which had not been previously apparent. Previous studies examined data aggregated at the quarterly level for Federal Reserve Districts and annual level for individual states. ${ }^{5}$ These series made events in the Second Federal Reserve District (New York) during the third quarter of 1931 appear as if they occurred at the same time and in reaction to events in the United Kingdom during the same quarter. The new data reveals that events in New York preceded events in the Britain and coincided with events in Germany.

This paper asks why bank distress in the central money market of the United States peaked at that time. The initially plausible answers - that links of debt or deposit left New York banks vulnerable to European difficulties - do not appear to explain the nature and timing of events. The bank distress in New York City during the summer of 1931 appears to have another explanation: intensified regulatory scrutiny.

The impetus for additional scrutiny began with the failure of The Bank of United States in December, 1930. Politicians throughout the state of New York criticized the Superintendent of Banks for his failure to forestall that institution's collapse. The state legislature demanded heightened vigilance and augmented the bank superintendent's staff. Additional regulatory resources came on-line during the summer of 1931. At the same time, legislatures questioned the superintendent's abilities and threatened to remove him from office. Additional resources enabled and political pressure prompted the superintendent's office to demonstrate his vigor and vigilance by closing (and either liquidating or merging) institutions in New York City. This surge in scrutiny generated the wave of bank distress in the summer of 1931 that appears correlated with events in continental Europe.

5 Richardson, "Bank Distress ... New Evidence." 


\section{Potential Links between New York and Europe}

An initial inspection of the evidence suggests direct connections existed between the banking crises in Germany and New York. The chronological correlation is striking. Figure 1 illuminates the relationship. The figure plots weekly hazard rates for liquidation and consolidation due to financial difficulties for banks in New York City. The probability of failure increased during July 1931, as a banking panic spread through central Europe. The probability rose higher when bank runs swept Germany and the German government shut down the nation's banking system. The probability of failure peaked in August, immediately after the reopening of banks in Germany but several weeks before Britain's departure from gold.

Recent research reveals reasons that events in Germany and New York might have been linked. Banks in New York held large sums deposited by European clients. The foreign branches of New York banks held deposits totaling over $\$ 600$ million dollars. New York banks organized over \$1.4 billion in loans to German corporations, utilities, and governments (including local, state, and national) from 1924 through $1930 .{ }^{6}$ Nearly $\$ 1$ billion of those loans floated in the United States were outstanding in June 1931. ${ }^{7}$ Econometric analysis of the links between the German and United State's economies during the 1930s suggests that German debt played a role, perhaps substantial, in transmitting financial shocks across the Atlantic. ${ }^{8}$ Analysis of equity returns also suggests a link through this channel. ${ }^{9}$

By participating in schemes designed to stem the Austrian crisis, banks in New York directly exposed themselves to risks rising on the continent. The Austrian Central Bank established an intricate series of cross deposits to covertly "direct funds to the Creditanstalt via

\footnotetext{
6 This information comes from the Senate Hearings on the Sale of Foreign Bonds or Securities in the United States, which took place from December 18, 1931 to February 10, 1932.

Robert Kuczynski, 1927 and 1932

Albrecht Ritschl and Samad Sarferaz, 2006

Hanan Morsy, 2002
} 
American and British banks - to compensate it for taking over the bankrupt Bodencreditanstalt (Iago Gil Aguado 2001, p. 199)." All of the American institutions involved in this shell game operated in New York City. The cross-deposit involved tens of millions of dollars, a substantial multiple of the capital of the banks involved, indicating that they took on risks large enough to put them out of business.

Table 1 provides details about the banks that experienced distress in New York City during the Great Depression. The first column indicates the date at which the bank closed its doors to depositors or consummated a consolidation with another institution. More than 60 percent of these transactions (16 out of 26) occurred during the two month period bounded by the failure of the Darmstadter- und Nationalbank on July 13, 1931 and Britain's departure from gold on September 21, 1931. Only two banks failed in the wake of Britain's departure from gold. One additional institution temporarily suspended payments during that period. ${ }^{10}$

\section{Domestic Sources of Distress}

While chronological patterns reveal correlations between events in New York and central Europe, further examination of the evidence suggests the correlation is coincidental, rather than causal. We again refer to Table 1. The fourth column, labeled Distress, shows that two types of distress predominated amongst banks in New York City. The letter $L$ indicates that a bank entered receivership and underwent liquidation. In all cases but one, the liquidation began at the behest of the Superintendent of Banks of the State of New York, after bank examiners determined that the institution faced financial difficulties so severe that it had to be closed to protect the interests of depositors and usually after determining that no other bank wished to

10 For the sake of comparison, only two banks failed in December 1930, a period that Friedman and Schwartz referred to as the First Banking Crisis. Only one bank failed during the fall of 1932 and winter of 1933, when gold drained from the Federal Reserve Bank of New York and the President declared a national banking holiday. 
consolidate with the afflicted institution. The exception was the Queesnboro National Bank, whose directors decided to turn the institution over to receivers. The letter $C$ indicates that financial difficulties compelled the bank to consolidate with another institution. Most of these consolidations occurred at the behest of regulators after examinations revealed looming financial problems. Typical situations involved banks lacking liquidity or banks whose capital had been consumed by investment losses. Regulators threatened to close such institution unless their directors resolved the problems by injecting additional funds or merging with another institution. Many institutions that liquidated (i.e. $L$ ) had also sought consolidation, but failed to reach an agreement with another organization in time to forestall receivership.

Contemporary observers (such as Federal Reserve agents, bank examiners, accountants, economists, and journalists) had access to an array of information unavailable to modern scholars, including detailed, daily data about the financial status of and events affecting commercial banks. Contemporary observers also had the ability to talk with the man on the spot and possessed in-depth knowledge about the institutions and issues at hand. Detailed records survive from several sets of contemporary observers. The first (and arguably the most important) is the St. 6386 database constructed by the Federal Reserve Board's Division of Bank Operations. Table 2 summarizes the results of the Division's analysis of bank suspensions. In 11 of 14 cases, the primary cause of suspension was the depreciation in the value of the bank's assets. In two cases, heavy withdrawals were the primary cause of suspension. In another case, a bank failed after losing a substantial share of its capital to embezzlement. Comments written on the St. 6386 forms discuss reasons for the depreciation in the value of the bank's portfolio, principally the declining value of stocks, corporate bonds, and real estate. In all cases, the comments refer to declines of domestic assets. In no instance do the comments refer to foreign 
investments or German debt.

The Division of Bank Operations also tracked consolidations due to financial difficulties. Table 3 summarizes the results of this endeavor. All but one of the banks forced to consolidate in 1931 suffered from frozen assets or impaired capital. The examiners who discovered these afflictions reached conclusions like Midwood Trust Company’s condition was “such as to necessitate its being taken over by some other institution."11 Long Island National Bank's health was "such as to necessitate an immediate absorption." "The condition of the International Trust Company was such as to make desirable their being taken over by a stronger institution." $" 13$ In almost all of these cases, the absorbing bank took all of the assets of the troubled bank in exchange for assuming the deposits and some, but not all, of the other liabilities of the troubled institution. The Division of Bank Operations attributed the financial difficulties to domestic factors. In no instance does the Division discuss international events, deposits, or debts.

Like the Division of Bank Operations, the New York State Bank Superintendent's office investigated the cause of suspension for each state-chartered bank, trust company, and private bank. These amounted to 13 of the 14 institutions that closed their doors to depositors during the summer of 1931. The superintendent released initial statements about the cause of each closure on the date that the institution closed its doors and in the weekly bulletin of the Department of Banking. Final conclusions appeared in the Department of Banking's Annual Report. So did information about the rate of recovery from institutions undergoing liquidation. These sources described the cause of Chelsea Bank's and Trust Companies demise to be "rumors" that circulated "which have caused abnormal withdrawals of deposits," prompting the examiners to close the bank to conserve its assets. In all other instances, the sources contained statements such

\footnotetext{
NARA, Bank Changes, Midwood Trust Company, NY, NY, August 10, 1931. Ibid, Bank Changes, Long Island National Bank, NY, NY, August 22, 1931.

Ibid, Bank Chagnes, International Trust Company, NY, NY, September 15, 1931.
} 
as 'because of a non-liquid condition and depreciation of its assets, it is unsafe and inexpedient to permit the institution to continue in business.' The Department of Banking attributed the financial difficulties of all of these institutions to domestic factors, particularly the declining values of securities, bonds, and real estate, which reduced the value and liquidity of banks' portfolios. In no instance does the Department of Banking discuss international factors, such as foreign deposits or German debt.

Contemporary conclusions are clear. During the summer of 1931, the banks that ceased operations did so for reasons unrelated to the financial crisis in Europe. The sources of distress were the declining value of domestic assets - principally real estate, stocks, and bonds - and withdrawals from banks which appeared to be headed for financial trouble. The banks that closed their doors or consolidated with other institutions did not due so because German debt declined in value or because foreign depositors withdrew funds. Widespread withdrawals did not occur in the summer of 1931. Deposits at New York City banks in August 1931 were comparable to deposits at New York City banks in August 1930. The small fall in deposits during the summer of 1931 (approximately 4 percent) resembled typical seasonal variation. ${ }^{14}$

Table 4 reveals why contemporary observers focused on domestic causes of bank distress. The table reports cross tabulations between the incidence of bank distress and measures of foreign exposure. The first cross tabulation shows that none of the banks that departed from the banking business in the summer of 1931 possessed foreign branches, while two of the banks that survived the summer possessed such branches. The second cross tabulation shows that none of the banks that departed from the banking business in the summer of 1931 possessed time

14 Data drawn from the column "New York Weekly Bank Statements" published each week in the New York Times and the compilation of member bank balance sheets released weekly by the Federal Reserve Bank of New York, entitled "New York City Reporting Member Banks", and republished in numerous periodicals including Bradstreet's Weekly, Dun's Review, The Commercial and Financial Chronicle, and the New York Times. 
deposits from financial institutions in foreign countries, while eight of the banks that survived the summer possessed such deposits. The third cross tabulation shows that none of the banks that departed from the banking business in the summer of 1931 belonged to syndicates that extended loans to Germany during the 1920 s, while four of the banks that survived the summer lead such syndicates. In sum, none of the banks that departed from the banking business during the summer of 1931 were exposed to foreign financial shocks, while many of the banks that survived the summer (and the depression) had such exposure.

A companion paper that we have written reinforces this point. ${ }^{15}$ It examines data drawn from the balance sheets of Federal Reserve member banks, for which information on foreign deposits, debts, and assets exists. For these banks, all measures of foreign exposure were inversely correlated with the probability of distress. In other words, bank with more foreign exposure experienced less distress during the depression of the 1930s.

\section{Intensified Regulatory Scrutiny}

The behavior of the New York's Banking Department changed during the summer of 1931. Eight months before, in December 1930, The Bank of United States failed. It was the fourth largest depository institution in New York and the eighth largest in the nation. From December 1930 through June 1931, "practically the entire examination force in the metropolitan district was engaged in the liquidation of the Bank of United States" ${ }^{16}$ The concentration of examination resources on this case compelled the superintendent's office to expand the size of its staff. The rigidity of civil service regulations, however, slowed the process and impeded the hiring of experienced individuals. Eventually, "it was necessary to obtain executive permission to employ temporary examiners not taken from Civil Service lists and to reinstate former

\footnotetext{
15 Richardson and Van Horn, "Fetters."

${ }^{16}$ Superintendent of Banks for the State of New York, Annual Report, p. 19.
} 
examiners whose wide experience was desperately needed ."17 The Civil Service Commission insisted that for each examiner appointed who was not a civil servant, an appointment had to be made from the civil service list, which at the time, included few individuals with the training, talent, or aptitude for bank-examination work. These restrictions slowed the department's effort to respond to the emergency.

The department managed to increase the examination staff to 192 members at the end of 1931, up from 131 in December 1930. In addition, for a period of seven months, the department “obtained the assistance of twenty-eight men whose services were donated by various banks as well as the aid of fifteen Federal Reserve examiners who were temporarily lent to the department." ${ }^{, 18}$ Bureaucratic delays and the time to train the new examiners meant that the size of the effective examination staff increased substantially during the summer of 1931. At the same time that these new resources came on line, the permanent examination staff for the metropolitan district, which had focused on The Bank of United States from January through June, finished that investigation and returned to regular duties. Thus, in the summer of 1931, the effective number of examiners in New York City increased substantially. The number of bank examinations, which had been conducted infrequently for many months, increased commensurately.

The examinations also increased in intensity. The banking department adopted "new regulations for the purpose of obtaining more complete information on loans and security portfolios." "19 These changes included new reporting forms designed to "instantly reflect trends and policies of each state bank and trust company" and new methods for "arriving at fair values

Ibid, Annual Report, p. 19.

Ibid,,Annual Report, p. 17.

19 Superintendent of Banks for the State of New York, Annual Report, p. 17. 
of securities. ${ }^{20}$ These innovations stemmed from a reorganization of the banking department begun in the spring of 1929 and completed in the wake of the failure of The Bank of United States.

The post-examination powers of the banking department also increased. In the spring, the state legislature passed several reform bills introduced at the request of the state bank superintendent. The first bill permitted the hiring of additional examiners in an emergency. The second reduced from 30 to 20 days the time allowed for filing claims against a bank by the superintendent after notice had been sent to creditors. The third allowed the superintendent to act on the findings of clearing house examinations as if they were examinations conducted by the state banking department. Two other bills failed to progress past the banking committee. One would have permitted the superintendent to consolidate banks overnight in emergencies. The other would have authorized the superintendent to remove officers of a bank upon evidence showing them responsible for improper conditions. ${ }^{21}$ The superintendent argued that the rejected reforms would have provided him with the ability to forestall the failure of The Bank of United States. Critics of the Superintendent, including many legislators on the banking committee, asserted that the superintendent possessed more than enough authority to have prevented the crisis had he acted when irregularities at The Bank of United States were first brought to his attention in 1929.

Criticism of the superintendent, Joseph Broderick, peaked in June, when the case against the directors of the Bank of United States reached trial. A New York Times headline blared "STATE CALLED LAX IN BANK FAILURES (emphasis in original)."22 Another headlined reported that the superintendent had been accused of "Gross Negligence" for his performance on

Ibid, Annual Report, p. 17.

21 "State Banking Bills," Wall Street Journal, (March 13, 1931), p. 8.

22 "State Called Lax in Bank Failures," New York Times, (June 14, 1931), p. 1. 
The Bank of United States. ${ }^{23} \mathrm{~A}$ former state attorney general circulated a letter calling for a general investigation of the banking department and drawing parallels between its performance in the current case and problems in the past. The chairman of the Republican State Committee sent a letter to Governor Roosevelt requesting an inquiry and demanding the removal of Superintendent Broderick. ${ }^{24}$ The state legislature discussed the creation of a special committee to investigate the banking department and considered a bill authorizing suits against state bank employees who performed their jobs negligently.

The chorus of criticism focused on the banking department's slow response after discovering the financial problems faced by The Bank of United States. In reaction, the superintendent testified that the irregularities which led to the bank's demise were first brought to his attention in the summer of 1929. Then, he believed that "he would have been 'gravely remiss in his sworn duty if he did not exhaust every possible resource to save the situation before deciding that the doors must be closed'." He allowed The Bank of United States to continue operations for more than a year, and during that time, to continue conducting transactions, "which he admits were dishonest even if inside the letter of the law," and to continue to accumulate losses, in hopes that some remedy for the situation would be found. ${ }^{25}$

In the summer of 1931, the superintendent planned to deal with such situations expeditiously, and requested an expansion of his powers to enable him to take control of banks whenever he deemed it in the public interest. He planned to encourage the consolidation of banks "in cases where it appeared the result would be generally beneficial. This tendency toward consolidation, resulting as it does in the disappearance of many independent units, effects a concentration of banking resources and improved management which should lend itself to the

23 "Waldman Urges Broderick Ouster," New York Times, (June 27, 1931), p. 2.

24 "Steuer Banks Macy on Banking Inquiry," New York Times, (June 26, 1931), p. 7.

25 “State Supervision of Banks," Wall Street Journal, (March 6, 1931), p. 2. 
development of sound policies and the elimination of unwarranted competition." 26

The impact of the superintendent's new policies and increased authority can be seen in the wave of examinations that swept New York City in the summer of 1931. New stringent procedures highlighted investment losses and potential problems at numerous institutions. The superintendent's office moved swiftly to rectify such shortfalls. The department demanded that the bank's shareholders, directors, and management come up with capital to cover the losses, or consolidate with other institutions, which typically required them to realize large losses (in many cases, their entire investment), or face seizure by the superintendent's office. A dramatic climax of the campaign came on August 5, when the Superintendent Broderick seized three banks (American Union, International Madison, and Times Square Trust), on the same morning. The seizures upset the plans of the joint legislative committee on banking to hold a hearing at the Bar Association Building that afternoon to discuss the performance of the banking department. The announcement cancelling the hearings noted that "the taking over of the three banks made it impossible for Mr. Broderick or the bankers to appear before the committee"27 During the next three weeks, Superintendent Broderick oversaw the liquidation of those three depositories, compelled the consolidation of an additional five New York City banks, and supervised the examination and sanctioning of number other institutions. His office remained so busy that the public hearings on his performance appear to have been postponed indefinitely.

In sum, bank supervision in New York City became more aggressive during the summer of 1931. It seems likely that the change stemmed from pressure on the bank superintendent, changes in the incentives and attitudes of the superintendent and his staff, the growth of resources available to the banking department, and the expansion of de jure and de facto

26 Superintendent of Banks for the State of New York, Annual Report, p. 7.

27 "Ignores Macy Plea for Banking Inquiry” New York Times, (August 6, 1931), p. 32. 
regulatory authority.

\section{Econometric Methods and Results}

Our empirical analysis compares competing explanations for the summer-1931 surge in bank suspensions in New York City. Several considerations shape our analysis. One consideration is the availability of evidence. ${ }^{28}$ For Federal Reserve member banks, call reports provide detailed data on seven measures of foreign exposure: (i) balances payable in dollars due from foreign branches of American banks, (ii) due from banks in foreign countries, (iii) due to banks in foreign countries, (iv) time deposits of other banks and trust companies in foreign countries, (v) foreign government bonds owned, (vi) other foreign securities owned, including bonds of municipalities, and (vii) number of foreign branches. Similar data does not exist for banks that did not belong to the Federal Reserve System. ${ }^{29}$

These seven dimensions of foreign financial exposure are closely correlated. Their covariance raises concerns about multicollinearity. To address this issue, we can create an index of foreign financial exposure by deriving the principal components from the seven measures of foreign financial exposure. The first principal component is a linear transformation of the vectors that explains the greatest possible variance in these vectors. This first principal component serves as our index. Banks for which the value of the index is lowest have the least foreign financial exposure. Banks for which the value of the index is highest have the most foreign financial exposure.

Another consideration is the different regulatory regimes for banks that belonged to and

28 See the appendix for a description of our data sources. See Richardson and Van Horn "Fetters" for additional details.

29 For non-member banks, data on foreign exposure is limited. The New York State Bank Superintendent's Office did not publish information on the topic, in large part, because non-members lacked substantial foreign operations. Rand McNally Bankers' Directory published limited information on the topic, consisting of the names of foreign correspondents institutions, and in some case, and in a few cases, foreign branches and foreign holdings. 
banks that did not belong to the Federal Reserve System. Federal Reserve rules prohibited member banks from investing in certain assets that non-member banks often held on their balance sheets. Fed policies encouraged member banks to invest in certain assets, such as shortterm commercial paper, that played a smaller role for non-member institutions. Federal Reserve rules required member banks to maintain larger reserves and more cash on hand than nonmember institutions. Finally, member banks had access to the services of the Federal Reserve, such as the discount window, that nonmember banks did not.

Both member and non-member banks underwent periodic examinations. Member banks submitted periodic financial reports to the Federal Reserve System. The dates on which these reports were collected coincided with the call dates for the Comptroller of Currency, which regulated and examined nationally chartered banks. The Federal Reserve also periodically examined member banks, including those with national and state charters. State chartered banks submitted periodic reports to the state bank superintendent and underwent periodic examinations by state bank examiners. State-chartered banks that belonged to the Federal-Reserve system were subject to both state and federal supervision.

Lack of data and different regulatory regimes compel us to focus on banks belonging to the Federal Reserve System and to exclude non-member banks from our analysis. This exclusion does not, in all likelihood, bias our conclusions. All extant information indicates that nonmember banks had little (and usually no) foreign operations and had limited (and usually no) foreign exposure. Non-member banks in New York City failed at extremely low rates. Their failures peaked during the period when failures for all other banks peaked (see Table 5 for details). These patterns are consistent with our conclusions.

An additional concern is the chronological pattern of bank distress. Figure 2 and Table 5 
illuminate these patterns. During 1931, bank distress in New York City appears to have been clustered in three periods. The first occurred in March, during the months following the demise of the Bank of United States and preceding the banking crisis in Austria. The spanned July and August, when banking problems beset Germany and when subordinates of the bank superintendent examined all of the state-chartered banks in New York City. The third followed Great Britain's abandonment of the gold standard and the Federal Reserve's interest-rate reaction to Britain's action. Figure 2 displays these three periods of risk as three periods of increased risk, separated by periods without bank distress. Table 5 displays these patterns by separating the data into four periods: the three described above and one additional period representing the rest of the contraction. These periods form the foundation of our analysis.

This periodization also encompasses patterns of regulatory activity in New York City. During 1931, the failure of the Bank of United States distorted schedules for state bank examinations. Liquidating the Bank of United States employed almost the entire state-bank examination staff full-time for the months of January through June. During this six-month period, the superintendent's office postponed regular examinations, and it hired and trained additional staff members. Examinations resumed in the month of July, under new and stricter standards. After August, examination schedule returned to normal. The Comptroller of the Currency and Federal Reserve System did not face the same manpower constraints, and they maintained their regular examination schedule throughout the year. Thus, state banks experienced no state examinations during our first analytic period, intense examinations during the second period, and regular examinations during the third and fourth periods. National banks experienced regular examinations across all four periods. As a result, the inspection regime for Federal Reserve member banks with national charters differed from the inspection regime for 
Federal Reserve members with state charters in one dimension. During July and August of 1931, state member banks faced heightened scrutiny, when examiners inspected their balance sheets under new, stricter standards. All of the state chartered banks that closed were taken over by state examiners in the wake of these examinations. ${ }^{30}$

These circumstances lend themselves to statistical methods akin to discrete-time survival analysis. We observe whether banks survived during a period conditional on their having survived through the previous period. This conditionality is captured by a panel-logit specification:

$$
D_{i t}=\sum_{t=1}^{4} \alpha_{t} P_{t}+\sum_{t=1}^{4} \beta_{t} P_{t} F_{i}+\sum_{j=1}^{J} \delta_{j} X_{i j}+\varphi P_{2} S_{i}+\varepsilon_{i t}
$$

The dependent variable, $D_{i t}$, equals one if during the period $t$, bank $i$ experienced distress, (i.e. ceased operations and either entered receivership or consolidated due to financial difficulties). The dependent variable equals zero otherwise. The dependent variable is regressed on a series of explanatory variables. $P_{t}$ is an indicator variable that equals one during period $t$ and zero otherwise. The coefficient, $\alpha_{t}$, indicates the baseline hazard for period $t . F_{i}$ indicates bank i's foreign exposure as measured by our index. $F_{i}$ is measured before the onset of risk in period 1. The effect of foreign exposure is allowed to vary across periods by interacting the variables $F_{i}$ and $P_{t}$. The coefficient, $\beta_{t}$, indicates whether foreign exposure increased or decreased the probability of distress during period $t . S_{i}$ equals one if bank $i$ is a state-chartered bank and zero otherwise. $X_{i j}$ is a vector of bank characteristics measured before the onset of risk. The letter $\mathrm{j}=$ $\{1, \ldots, \mathrm{J}\}$ indexes the characteristics. These characteristics include net worth as a share of total

30 NARA, Bank Changes, Prisco State Bank, NY, NY, July 28, 1931. Midtown Bank, NY, NY, August 4, 1931. American Union Bank, NY, NY, August 5, 1931. International-Madison Bank and Trust Company, NY, NY, August 5, 1931. Times Square Trust Company, NY, NY, August 5, 1931. Midwood Trust Company, NY, NY, August 10, 1931. Globe Bank and Trust Company, NY, NY, August 22, 1931. Bank of Europe Trust Company, NY, NY, August 28, 1931. 
resources, reserves as a share of total resources, and deposits as a fraction of total liabilities. The coefficients for these variables possess signs and magnitudes consistent with previously published studies. These coefficients indicate that banks with higher net worth as a percentage of assets failed less often than banks with lower net worth. Banks with more reserves as a percentage of resources failed less often than banks with fewer reserves. Banks with more liquidity and lower cost of capital failed at lower rates than other institutions. For brevity, we do not report these coefficients in Table $6 .^{31}$

The coefficients of interest are those indicating the influence of foreign financial exposure, $\beta_{1}$ through $\beta_{4}$, and the impact of intensive examinations of state banks during the second period (i.e. July and August 1931), $\varphi$. Table 6 reports these coefficients. ${ }^{32}$ Column (1) reports the baseline hazard rates estimated without other covariates. The baseline rates for periods one through four were 1.3 percent, 12.7 percent, 5.8 percent, and 3.1 percent respectively. ${ }^{33}$ Column (2) reports the model with the inclusion of our index for foreign exposure. The coefficients indicate that banks with more foreign exposure failed less often than banks with less exposure. The magnitude of the effect was substantial. In the first period, increasing foreign exposure by one standard deviation reduced the probability of distress from 1.3 percent to less than 0.0013 percent. In the second period, increasing foreign exposure by one standard deviation reduced the probability of distress from 12.7 percent to less than 0.0005 percent. In sum, the more foreign exposure possessed by banks, the lower the likelihood of their failure. This econometric result seems reasonable, since all of the banks in New York City with substantial foreign financial exposure survived the depression. Most continued to pay dividends

31 Note that we checked for robustness by running specifications including a wide array of bank characteristics on the right-hand side. These variations did not substantially alter our results. See Richardson and Van Horn "Fetters" for details.

32 We estimate our model as a logistic panel. We report Huber-White standard errors clustered on individual banks.

33 You convert the coefficient into the probability of failure with the formula $\mathrm{P}($ distress $)=1 /(1+\mathrm{e}($-coefficient $))$. 
throughout the contraction. Column (3) presents the full model, where the last coefficient indicates the impact of intensified state examinations. The examinations increased the odds of distress nearly 4-fold.

Table 7 puts these estimates in perspective. Column (1) indicates the predicted probability of failure in each period for state member banks. Column (2) indicates the predicted probability of failure in each period for national banks. Column (3) indicates the difference for each period between (1) and (2). In the first, third, and fourth periods, the national banks experienced distress at higher rates than state member banks (in the later two periods, significantly so). During the second period, however, the risk of distress for state member banks exceeded the risk for national banks by more than twelve percent. Our model attributes indicates that this difference arose due to the intensified inspection regime. Without these intense inspections, our model indicates the risk of distress for state member banks would have been less than 6 percent during the second period.

\section{Discussion}

The statistical and historical evidence presented in this essay point to a common conclusion. The chronological correlation of the banking crises in Germany and New York City was coincidental, not causal. Foreign exposure did not lead to distress among banks at the center of the American money market. An intensified inspection regime, which was a delayed reaction to the failure of the Bank of United States, caused the surge of bank liquidations and consolidations in New York City during July and August of 1931.

This realization raises several issues regarding bank distress during the Great Depression. The first pertains to the uniqueness of the United States central money market. Scholars have 
long recognized that the pattern of bank distress in New York City differed from the pattern of distress for the national as a whole. In New York City, few banks closed their doors to depositors; in the rest of the nation, nearly a third of all banks went out of business. Our study suggests that the behavior of the New York state banking department had much to do with the fates of banks in the central money market. The superintendent's office actively merged weak banks with stronger institutions. Banking law required banks in New York City to hold larger reserves and greater capital than depository institutions elsewhere in the nation. These legal requirements left a large cushion between the onset of difficulties and the point of no return. The superintendent used this cushion as a window of opportunity to resolve bank distress short of receivership. The superintendent's vigilance meant that few institutions failed in New York City and those that did go out of business returned substantial sums to depositors.

A second issue is the political economy of bank regulation. Regulators determined the fate of many banks. What influenced the decisions made by bank regulators, such as the New York Superintendent of Banks and his subordinates? Ideology, experience, politics, legislation, and self interest all played a part. The superintendent's treatment of troubled banks changed over time. Changing economic conditions may have been one reason. The optimal method of resolving financial difficulties depends on the short-term prospects for sustaining cash flow and the long-term prospects for earning profits. Both factors fluctuated during the 1930s. Changing legislation was another reason. Politicians provided the banking department with additional tools for dealing with bedeviled banks. Political decisions also changed the incentives of the superintendent, who had been appointed as a reformer in the spring of 1929 and was criticized as incompetent two years later. The failure of The Bank of United States was the principal cause of criticism. Its demise led to political pressures which pushed the superintendent of banks to take a 
prophylactic approach towards imperiled banks.

A third issue concerns correlations between events in financial centers in the United States and Europe. Causal links may have created some of these correlations. But, this essay shows that coincidences created others. This realization suggests that there is a danger of drawing false inferences from correlations between events in different countries during the Great Depression. With so many things going wrong in so many countries in such a short span of time, numerous chronological correlations would have been generated by random chance.

A final issue concerns the international transmission of the banking crisis in the summer and fall of 1931. Numerous channels could have transmitted the financial crisis across the Atlantic. Direct links between banks in Europe and the United States appear to have been plausible candidates, but this essay demonstrates that those direct links did not, in fact, spread the affliction. Thus, golden fetters remain the principal explanation for the trans-Atlantic transmission of the financial panic in the fall of 1931.

\section{Appendix: Data Sources Used for Statistical Analysis}

Several sources provide the data that we employ in our econometric analysis. Rand McNally Bankers' Directory describes correspondent network, foreign branches, and international transactions services provided to consumers. The Senate Hearings on the Sale of Foreign Bonds or Securities in the United States reports loans to Germany arranged by banks in New York and outstanding during the summer of 1931. Call reports collected by the Federal Reserve Board and Comptroller of Currency provide detailed information for banks belonging to the Federal Reserve System. For state-chartered member banks, balance sheets and income statements survive for the December and June calls for the first five years of the depression (i.e. December 1929 through December 1933). For national banks, balance sheets survive from the December 1929 and December 1931 calls. Income statements survive from the December 1929, June 1931, and December 1931 calls. The balance sheets provide detailed data about bank's foreign exposure. Schedule $\mathrm{G}$ indicates holdings of foreign government bonds and other foreign securities. Schedule I indicates balances due in dollars and foreign currencies from foreign banks and foreign branches of U.S. banks. Schedule J indicates balances due to banks in foreign countries. Schedule L indicates time deposits of foreign banks and trust companies. Schedule D 
indicates the number of branches in foreign countries. A balance sheet also exists for each foreign branch, which provides additional information about overseas operations.

Information on bank distress - including temporary suspensions, liquidations, mergers of solvent institutions, and consolidations forced by financial difficulties - comes from the archives of the Federal Reserve Board of Governors' Division of Bank Operations. Combining the St. 6386 forms and the bank-balance sheet data described above yields a cross-sectional database of banks on the eve of the financial crisis at the beginning of 1931. The database contains more information about banks' characteristics, financial health, and fates than any other extant source. Data on economic conditions comes from several sources. Bradstreet's Weekly, Dun's Review, The Commercial and Financial Chronicle, the Federal Reserve Bulletin, and the Annual Reports of the Federal Reserve Board and the Federal Reserve Bank of New York provide data on building permits, business failures, commodity prices, market interest rates, Federal Reserve discount rates, prices, and industrial production. The same sources also data on international flows of gold, goods, and funds. 
Table 1

Bank Distress in New York City, 1929 to 1933

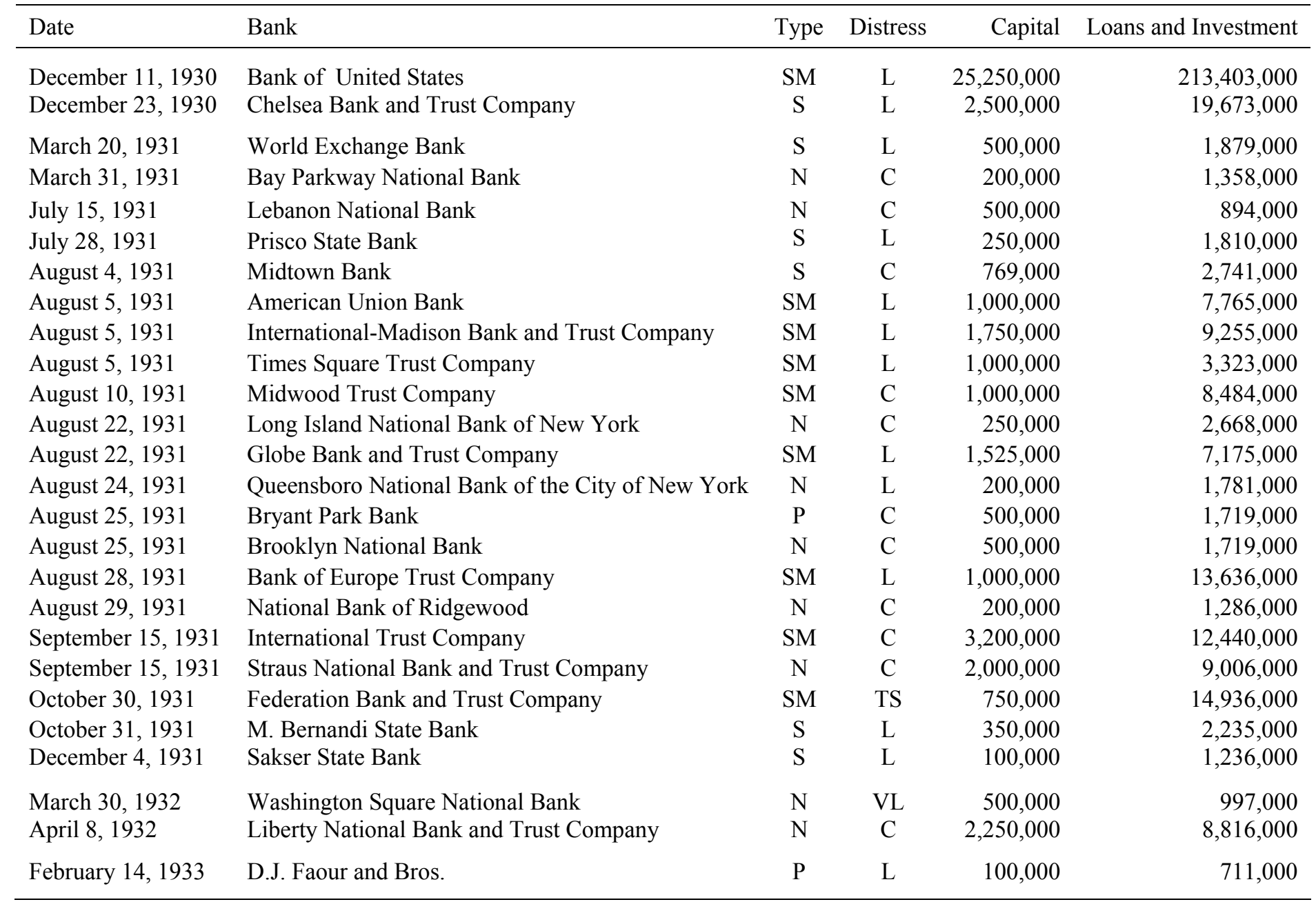

Notes: $N$ indicates national bank. $S$ indicates state bank. $S M$ indicates a state bank that is a member of the Federal Reserve System. $P$ indicates private bank. $L$ indicates liquidation. $C$ indicates a consolidation due to financial difficulties. $T S$ indicates temporary suspension. $V L$ indicates a voluntary liquidation. Source: St. 6386 Database, see footnote 1 for details 
Table 2

Causes of Suspensions in New York City, 1929 through 1933

\begin{tabular}{|c|c|c|c|c|c|c|c|}
\hline \multirow{2}{*}{$\begin{array}{l}\text { Date of } \\
\text { Suspension }\end{array}$} & \multirow[t]{2}{*}{ Name of Bank } & \multirow[t]{2}{*}{ Deposits } & \multirow{2}{*}{$\begin{array}{c}\text { Deposit } \\
\text { Losses }\end{array}$} & \multirow{2}{*}{$\begin{array}{l}\text { Days } \\
\text { Lost }\end{array}$} & \multirow[t]{2}{*}{ Borrowings } & \multicolumn{2}{|c|}{ Causes of Suspension } \\
\hline & & & & & & Primary & Contributing \\
\hline December 11, 1930 & Bank of United States & $202,965,000$ & $41,965,000$ & 78 & & Assets & Withdrawals \\
\hline December 23, 1930 & Chelsea Bank and Trust Company & $18,801,000$ & & & & Withdrawals & Assets \\
\hline March 20, 1931 & World Exchange Bank & $1,910,000$ & & & 200,000 & Assets & \\
\hline July 28, 1931 & Prisco State Bank & $1,902,000$ & & & & Defalcation & \\
\hline August 5, 1931 & American Union Bank & $7,939,000$ & 845,000 & 36 & 628,000 & Assets & Withdrawals \\
\hline August 5, 1931 & International-Madison Bank & $7,778,000$ & 967,000 & 36 & $1,004,000$ & Assets & Withdrawals \\
\hline August 5, 1931 & Times Square Trust Company & $2,882,000$ & $1,444,000$ & 36 & 300,000 & Assets & Withdrawals \\
\hline August 22, 1931 & Globe Bank and Trust Company & $7,426,000$ & $2,060,000$ & 53 & 973,000 & Assets & Withdrawals \\
\hline August 24, 1931 & Queensboro National Bank & $2,492,000$ & & & & Withdrawals & \\
\hline August 28, 1931 & Bank of Europe Trust Company & $12,807,000$ & $3,307,000$ & 59 & 200,000 & Assets & \\
\hline October 30,1931 & Federation Bank and Trust Company & $13,390,000$ & $1,220,000$ & 31 & 858,000 & Assets & Withdrawals \\
\hline October 31,1931 & M. Bernandi State Bank & $1,253,000$ & 153,000 & 31 & 750,000 & Assets & \\
\hline December 4, 1931 & Sakser State Bank & $1,074,000$ & 134,000 & 65 & 400,000 & Assets & \\
\hline February 14, 1933 & D.J. Faour and Bros. & 527,000 & & & 78,000 & Assets & \\
\hline
\end{tabular}

Notes: Deposits indicates the deposits held by the bank on the last call date before suspension. Deposit losses indicates the decline in deposits between the last call date and the date of suspension. The information needed to calculate this figure exists only in the listed cases. Days lost indicates the number of days between the last call date and the date of suspension, or in other words, the number of days over which the decline in deposits was calculated. Borrowings indicates loans outstanding from the Federal Reserve and other banks on the date of suspension. See Section 2 for definitions of the primary and contributing causes of suspensions. Asset indicates that slow, doubtful, or worthless investments were a source of bank distress. Withdrawal indicates that withdrawals of deposits were a source of bank distress. Defalcation indicates that embezzlement was a source of bank distress.

Source: St. 6386 Database, see footnote 1 for details. 
Table 3

Consolidations Due to Financial Difficulties in New York City, 1929 through 1933

\begin{tabular}{|c|c|c|c|c|}
\hline Date & Consolidating Bank & Absorbing Bank & Description of consolidation & Disposition \\
\hline March 31, 1931 & Bay Parkway National Bank & Lafayette National Bank & & \\
\hline July 15,1931 & Lebanon National Bank & Manufacturers Trust & All except capital & Branch \\
\hline August 4, 1931 & Midtown Bank & Manufacturers Trust & All except capital & Discontinued \\
\hline August 10, 1931 & Midwood Trust & Manufacturers Trust & All except capital & Branch \\
\hline August 22, 1931 & Long Island National Bank & National City Bank & Liquidation basis & Branch \\
\hline August 25, 1931 & Bryant Park Bank & Manufacturers Trust & Assets and deposits & Discontinued \\
\hline August 25, 1931 & Brooklyn National Bank & Manufacturers Trust & Assets and deposits & Discontinued \\
\hline August 29, 1931 & National Bank of Ridgewood & The Richmond National Bank & All except capital & Branch \\
\hline September 15, 1931 & International Trust & Continental Bank and Trust & & Branch \\
\hline September 15,1931 & Straus National Bank and Trust & Continental Bank and Trust & & Branch \\
\hline April 8, 1932 & Liberty National Bank and Trust & Harriman National Bank and Trust & & Branch \\
\hline
\end{tabular}

Notes: The consolidating bank was the institution suffering financial difficulties. The absorbing bank was a healthy institution which took over the affairs of its weaker compatriot. Description of consolidation describes the financial details of the transaction. "All except capital" indicates that the absorbing bank assumed all liabilities except the capital liability of the consolidating institution and acquired all of its assets. "Assets and deposits" indicates that the absorbing bank assumed only the deposit liabilities of the consolidating institution while acquiring all of its assets. "Liquidation basis" indicates that the absorbing bank acquired all assets and liabilities of the consolidating bank, and if the assets proved more valuable than the obligations of the consolidating institution, returned a portion of the surplus to the shareholders. Disposition indicates what became of the offices of the consolidating bank. "Branch" indicates that the offices of the consolidating bank became a branch of the absorbing institution. "Discontinued" indicates that the offices of the consolidating bank ceased operations.

Source: St. 6386 Database, see footnote 1 for details.. 
Table 4

Foreign Exposure and Bank Distress

Selected Cross-Tabulations for National and State-Member Banks, 1931

\begin{tabular}{|c|c|c|}
\hline & \multicolumn{2}{|c|}{ Foreign Branches } \\
\hline & No & Yes \\
\hline No Distress & 62 & 2 \\
\hline \multirow[t]{3}{*}{ Distress } & 16 & 0 \\
\hline & \multicolumn{2}{|c|}{ Foreign Deposits } \\
\hline & No & Yes \\
\hline No Distress & 56 & 8 \\
\hline \multirow[t]{3}{*}{ Distress } & 16 & 0 \\
\hline & \multicolumn{2}{|c|}{ German Loans } \\
\hline & No & Yes \\
\hline No Distress & 60 & 4 \\
\hline Distress & 16 & 0 \\
\hline
\end{tabular}

Sources: See text. 
Table 5

Bank Supervision and Distress in New York City

January 1930 until the National Banking Holiday in March 1933

\begin{tabular}{|c|c|c|c|c|c|}
\hline Federal Reserve & & & \multicolumn{2}{|r|}{ Member } & Nonmember \\
\hline Charter & & National & & State & State \\
\hline & \# & $\%$ & $\#$ & $\%$ & - \\
\hline
\end{tabular}

Period at Risk

Begin

1. January 1,1930

2. July 1,1931

3. September 1,1931

4. December 1,1931

$\begin{array}{llllll}51 & 1 & 2.0 & 29 & 0 & 0.0\end{array}$

$\begin{array}{lll}33 & 1 & 3.0\end{array}$

to June 31,1930

$\begin{array}{llllll}50 & 4 & 8.0 & 29 & 6 & 20.7\end{array}$

to August 31, 1931

$46 \quad 2$

to November 31, 1931

to Bank Holiday

$\begin{array}{llllll}44 & 2 & 4.6 & 22 & 0 & 0.0\end{array}$

$\begin{array}{lll}32 & 2 & 6.3\end{array}$

January 1, 1930

to Bank Holiday

$\begin{array}{lll}51 & 9 & 17.6\end{array}$

$29 \quad 8 \quad 27.6$

$\begin{array}{lll}33 & 5 & 15.2\end{array}$

Notes: The column headed \# indicates the number of banks in operation at the beginning of the period. The column headed - indicates the number of banks experiencing distress and departing from the banking business during that period. The column headed $\%$ indicates the percentage of banks experiencing distress and departing from the banking business during that period.

Source: See text. 
Table 6

Panel Logit Estimates of Probability of Distress

Dependent Variable: Distressed Departures from the Banking Business

\begin{tabular}{|c|c|c|c|}
\hline & $(1)$ & $(2)$ & (3) \\
\hline Period 1 - January through June 1931 & $\begin{array}{l}-4.37 \\
{[1.01]}\end{array}$ & $\begin{array}{r}1.33 \\
{[2.41]}\end{array}$ & $\begin{array}{r}0.99 \\
{[2.39]}\end{array}$ \\
\hline Period 2 - July and August 1931 & $\begin{array}{l}\mathbf{- 1 . 9 3} \\
{[0.34]}\end{array}$ & $\begin{array}{r}0.24 \\
{[2.48]}\end{array}$ & $\begin{array}{r}0.36 \\
{[2.90]}\end{array}$ \\
\hline Period 3 - September through November 1931 & $\begin{array}{l}-2.79 \\
{[0.52]}\end{array}$ & $\begin{array}{r}0.24 \\
{[2.44]}\end{array}$ & $\begin{array}{r}0.61 \\
{[2.47]}\end{array}$ \\
\hline Period 4 - December 1931 until Bank Holiday & $\begin{array}{l}-3.45 \\
{[0.72]}\end{array}$ & $\begin{array}{r}0.31 \\
{[3.05]}\end{array}$ & $\begin{array}{r}0.66 \\
{[3.09]}\end{array}$ \\
\hline Interaction Terms & & & \\
\hline Period 1 and Index of Foreign Exposure & & $\begin{array}{l}-3.50 \\
{[1.36]}\end{array}$ & $\begin{array}{l}\mathbf{- 3 . 1 8} \\
{[1.33]}\end{array}$ \\
\hline Period 2 and Index of Foreign Exposure & & $\begin{array}{l}-5.07 \\
{[2.15]}\end{array}$ & $\begin{array}{l}-6.88 \\
{[2.79]}\end{array}$ \\
\hline Period 3 and Index of Foreign Exposure & & $\begin{array}{l}-3.61 \\
{[3.12]}\end{array}$ & $\begin{array}{l}-3.27 \\
{[3.03]}\end{array}$ \\
\hline Period 4 and Index of Foreign Exposure & & $\begin{array}{l}-2.35 \\
{[1.63]}\end{array}$ & $\begin{array}{l}-2.02 \\
{[1.44]}\end{array}$ \\
\hline Period 2 and Intensified State Examination & & & $\begin{array}{r}1.73 \\
{[0.83]}\end{array}$ \\
\hline Vector of Bank Characteristics & No & Yes & Yes \\
\hline Observations & 293 & 293 & 293 \\
\hline Log-psuedolikelihood & -59.6 & -55.3 & -52.8 \\
\hline Wald Chi Squared & 102.5 & 101.0 & 97.3 \\
\hline Wald Chi Squared Degrees of Freedom & 4 & 11 & 12 \\
\hline
\end{tabular}

Notes: Robust standard errors clustered for each bank appear within brackets below coefficients. Boldfaced font indicates significant at 5 percent level.

Sources: See text. 
Table 7

Impact of Intensified Inspection Regime

Predicted Probability of Failure Across Four Periods at Risk

\begin{tabular}{|c|c|c|c|c|c|c|}
\hline \multicolumn{4}{|c|}{ Period at Risk } & \multirow{2}{*}{$\begin{array}{r}\text { State Member } \\
\text { Banks } \\
\text { (1) }\end{array}$} & \multirow{2}{*}{$\begin{array}{r}\text { National } \\
\text { Banks } \\
(2)\end{array}$} & \multirow{2}{*}{$\begin{array}{r}\text { Difference } \\
\text { (3) }\end{array}$} \\
\hline & Begin & & End & & & \\
\hline Period 1 & January 1, 1930 & to & June 31, 1930 & 1.01 & 1.38 & 0.37 \\
\hline Period 2 & July 1, 1931 & to & August 31, 1931 & 20.69 & 8.00 & -12.69 \\
\hline Period 3 & September 1,1931 & to & November 31, 1931 & 4.31 & 6.54 & 2.23 \\
\hline Period 4 & December 1, 1931 & to & Bank Holiday & 2.35 & 3.42 & 1.07 \\
\hline
\end{tabular}

Source: Estimates reported in Table 6. 
Figure 1

Weekly Hazard for Liquidation and Consolidation Due to Distress

New York City, July 1930 through March 1933

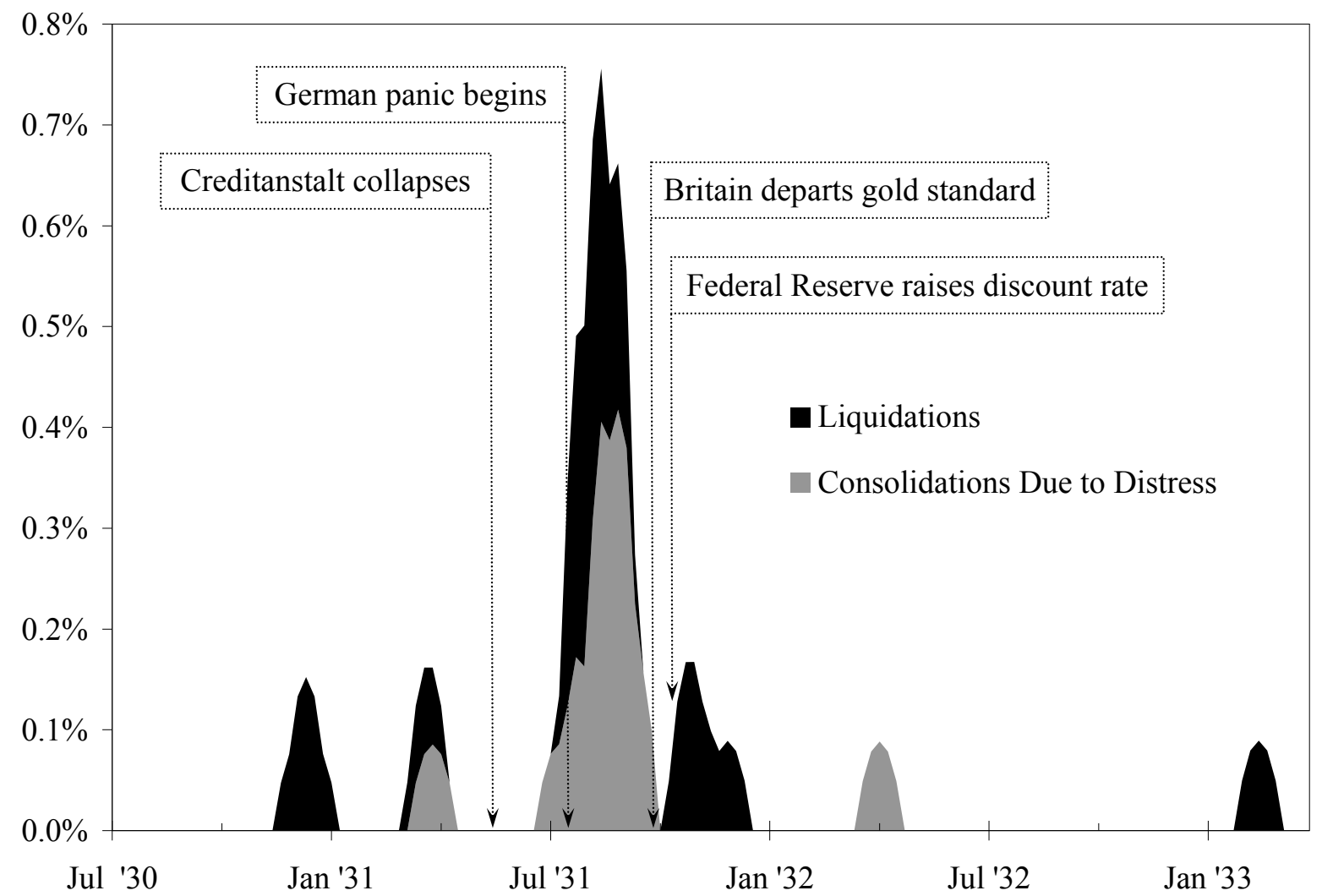

Notes: The hazard function is a non-parametric estimate constructed by smoothing raw hazard rates (i.e. the number of bank liquidations divided by the number of banks at risk each week and the number of consolidations due to financial difficulties divided by the number of banks at risk in each week). The kernel is Epanechnikov. The bandwidth is two weeks, which is wide enough to reveal trends without obscuring short-term shifts in the probability of failure.

Source: See text. 


\section{References}

Aguado, Iago Gil. "The Creditanstalt Crisis of 1931 and the Failure of the Austro-German Customs Union Project.” The Historical Journal 44, no. 1 (2001): 199-221.

Board of Governors of the Federal Reserve System. Annual Report. Washington, D.C.: GPO: various dates.

Reports of Condition of (Federal Reserve Member) Banks. Unpublished records, various calls.

-------- Bulletin. Washington, D.C.: GPO, various dates.

Bradstreet's Weekly, various dates.

Commercial and Financial Chronicle, various dates.

Dun's Review: A Weekly Survey of Business Conditions in the United States and Canada, various dates.

Eichengreen, Barry. Golden Fetters: The Gold Standard and the Great Depression, 1919-1939. New York: Oxford University Press, 1992.

Federal Reserve Bank of New York. Annual Report. New York: Federal Reserve. 1928-1933.

Friedman, Milton and Anna J. Schwartz. A Monetary History of the United States, 1867 to 1960. Princeton, N.J.: Princeton University Press, 1963.

Kuczynski, Robert. American Loans to Germany (1924-26). New York: Macmillian, 1927.

----- Bankers' Profits from German Loans. Washington, D.C.: The Brookings Institution, 1932.

Morsy, Hanan. International Financial Crisis Contagion. Mimeo.

National Archives and Records Administration, Record Group 82, Federal Reserve Central Subject File, file number 434.-1, "Bank Changes 1921-1954 Districts 1929-1954 Consolidations, Suspensions and Organizations-St. 6386 a,b,c, (By States) 1930-1933.”

New York Times, various dates.

Office of the Comptroller of the Currency. Unpublished examination reports and letters pertaining to national banks in New York City, 1929 and 1931.

Rand Mc Nally. Rand-McNally Bankers' Directory. Chicago: Rand McNally and Company, 1929-1933. 
Richardson, Gary. "The Records of the Federal Reserve Board of Governors in the National Archives of the United States," Financial History Review 13, no. 1 (2006): 123-134.

---- "Bank Distress during the Great Contraction, 1929 to 1933, New Evidence from the Archives of the Board of Governors" NBER Working Paper w12590, Cambridge, MA, December 2006.

2006b. "Quarterly Data on the Categories and Causes of Bank Distress during the Great Depression,” NBER Working Paper w12715, Cambridge, MA, December 2006.

---- "Correspondent Clearing and the Banking Panics of the Great Depression," This Journal 67, no. 3 (2007): 643-671.

Richardson, Gary and Patrick Van Horn. "Fetters of Debt, Deposit, or Gold?" NBER Working Paper w12983, Cambridge, MA, March 2007.

Ritschl, Albrecht and Samad Sarferaz. Currency vs. Banking in the German Debt Crisis of 1931. Mimeo.

Superintendent of Banks for the State of New York. Annual Report of the Superintendent of Banks. Albany, NY: J.B. Lyon Company, 1929-1932.

Temin, Peter. Lessons from the Great Depression. Cambridge, MA: MIT Press, 1989.

U.S. Committee on Finance, $72^{\text {nd }}$ Congress, $1{ }^{\text {st }}$ Session. Sale of foreign bonds or securities in the United States: Hearings on S.R. $72^{\text {nd }}$ Congr., $1^{\text {st }}$ sess., 1932.

Wall Street Journal, various dates. 